TITLE:

\title{
Hydrothermal decomposition of various crystalline celluloses as treated by semi-flow hot- compressed water
}

\author{
$\operatorname{AUTHOR}(\mathrm{S})$ :
}

Abdullah, Rosnah; Ueda, Kazuyoshi; Saka, Shiro

\section{CITATION:}

Abdullah, Rosnah ... [et al]. Hydrothermal decomposition of various crystalline celluloses as treated by semi-flow hot-compressed water. Journal of Wood Science 2014, 60(4): 278286

ISSUE DATE:

2014-05-23

URL:

http://hdl.handle.net/2433/198674

\section{RIGHT:}

The final publication is available at Springer via http://dx.doi.org/10.1007/s10086-0141401-7.; この論文は出版社版でありません。引用の際には出版社版をご確認ご利用くだ さい。; This is not the published version. Please cite only the published version. 
1 Hydrothermal decomposition of various crystalline celluloses as treated by

2 semi-flow hot-compressed water

3

4 Rosnah Abdullah and Shiro Saka*

5 Department of Socio-Environmental Energy Science,

6 Graduate School of Energy Science, Kyoto University,

7 Yoshida-Honmachi, Sakyo-ku 606-8501, Kyoto, Japan.

8

9 Kazuyoshi Ueda

10 Department of Advanced Materials Chemistry,

11 Graduate School of Engineering, Yokohama National University,

12 Yokohama, 240-8501, Japan.

13

14 *Shiro Saka

15 Tel/Fax: +81(0)75 7534738

16 Email address: saka@energy.kyoto-u.ac.jp

17

18

19

20

21

22

23

24

25

26

27

28

29

30

31

32 


\section{Abstract}

35 Various types of crystalline celluloses I, II, III, III II $_{\text {IV }}$ IV $_{\mathrm{I}}$ and $\mathrm{IV}_{\text {II }}$ that have been adjusted for their degree of polymerization $(D P)$ were treated by semi-flow hot-compressed water (HCW) at $230-270^{\circ} \mathrm{C} / 10 \mathrm{MPa} / 15 \mathrm{~min}$ in order to study their chemical decomposition. The treatments resulted in either partial or complete decomposition of the celluloses and the decomposed products were primarily recovered as hydrolyzed, dehydrated and fragmented ones as well as organic acids in the water-soluble (WS) portions. Their results of chemical decomposition and its kinetics revealed that the celluloses decomposition is dependent on the types of crystalline celluloses as well as temperature of the HCW treatment. The outcome from the WS portions at $270^{\circ} \mathrm{C} / 10 \mathrm{MPa} / 15 \mathrm{~min}$ showed that the degree of difficulty for decomposition is lower in group II (cell II, cell $\mathrm{III}_{\mathrm{II}}$, cell $\mathrm{IV}_{\mathrm{II}}$ ) than group I (cell I, cell $\mathrm{III}_{\mathrm{I}}$, cell $\mathrm{IV}_{\mathrm{I}}$ ), indicating that group II is less resistant to decomposition by HCW treatment. Therefore, the decomposition behaviors of the cellulose are due to the inherent differences in the crystalline structures.

Keywords Cellulose, Cotton linter, Crystalline structure, Hydrolysis, Semi-flow hot- 


\section{Introduction}

Currently, almost all ethanol from renewable carbon is obtained from food-based sources such as starch and molasses. The shortage of capacity and competition from food requirement drives the need for lignocellulose, such as grasses and woods, to serve carbon resources for promising biofuels [1]. Cellulose as one of the main components in lignocellulose with approximate production of $1.5 \times 10^{12}$ tons each year globally has high potential to be exploited for this purpose [2, 3]. It can be chemically converted into fermentable saccharides, however, this is usually hindered by its great resistance to hydrolysis [4].

Cellulose is a linear crystalline homopolymer consisting of $\beta$-1,4-linked Dglucopyranose units. It exists in six known polymorphs of celluloses (I, II, III I, IIIII, IV I, IV identified by their characteristic X-ray diffraction (XRD) patterns as well as ${ }^{13} \mathrm{C}$ nuclear magnetic resonance (NMR) spectra. In nature, cellulose has high degree of polymerization $(D P)$, in a range of about 6000 to 15000 glucopyranose units [5] which makes it highly crystalline and not easy to be separated or dissolved in almost any solvents [6,7]. Thus, numerous biological, chemical, and/or physical treatments such as enzymatic saccharification, acid/alkali treatments, steam explosion, supercritical and subcritical treatments have been applied and developed for cellulose hydrolysis [8-14].

Hydrothermal treatment in hot-compressed water $(\mathrm{HCW})$ has been proposed as a promising method to hydrolyze cellulose mostly due to its non-toxic, non-catalytic and environmentally benign properties [15-18]. Furthermore, over conventional method, it has advantages such as limited corrosion problem, no sludge generation, low capital and operational cost, as well as no significant degradation of cellulose at normal operating conditions [19]. The conventional methods such as acid/alkali treatment and acid/alkali pretreatment followed by enzymatic hydrolysis are associated with serious economic and environmental constraints due to the heavy use of chemicals.

Hot-compressed water is highly pressurized, high temperature liquid water at subcritical condition, below the critical point of water at $374^{\circ} \mathrm{C} / 22.1 \mathrm{MPa}$ [20]. It is characterized by a higher ionic product and thus higher concentration of $\mathrm{H}^{+}$and $\mathrm{OH}^{-}$ions, compared to ambient water, offering a highly interesting reaction medium for hydrolysis processes. In addition, acid neutralization is not required because the concentration of $\mathrm{H}^{+}$ion is a function of temperature, and decreases when the temperature is lowered. Many studies have confirmed that cellulose can be largely hydrolyzed in subcritical water without addition of a catalyst [21-26]. 
The experimental results using a flow-type HCW treatment showed that glucose yield

103

104

105

106

107

108

109

110

111

112

113

114

115

116

117

118

119

120

121

122

123

124

125

126

127

128

129

130

131

132

133 increases with increasing temperature [27]. It has less significant degradation reactions as compared with batch-type treatment that makes it preferable for hydrolysis process of lignocellulose [28-30]. It has been reported that 4-22\% of cellulose could be hydrolyzed by flow-type $\mathrm{HCW}$ treatment $\left(200-230^{\circ} \mathrm{C} / 34.5 \mathrm{MPa} / 15 \mathrm{~min}\right)$ [31].

To the best of authors' knowledge, studies have been done on analysis of cellulose hydrolysis by using HCW treatment; however, the comprehensive investigation has been rarely conducted on various crystalline celluloses as feedstocks. The physical characteristics such as crystalinity and $D P$ of various crystalline cellulose residues as treated by semi-flow $\mathrm{HCW}$ were thoroughly explored in previous study together with a brief evaluation on the water-soluble (WS) portions [32]. Therefore, as a further approach, the primary objective of this work is to study quantitatively the chemical decomposition from various crystalline celluloses as treated by semi-flow HCW through the yields of WS portions.

\section{Materials and Methods}

Preparation of various types of crystalline cellulose samples

Cotton linter (Buckeye 1AY-500), in the form of cellulose I (cell I), was used to prepare various types of crystalline celluloses. Cellulose II (cell II) was prepared from cell I through mercerization by soaking it into $20.0 \%$ of aqueous $\mathrm{NaOH}$ solution for $24 \mathrm{~h}$ at ambient condition of temperature $\left(20^{\circ} \mathrm{C}\right)$ and pressure $(0.1 \mathrm{MPa})$, followed by washing thoroughly with water and freeze-drying [33]. As for celluloses $\mathrm{III}_{\mathrm{I}}$ (cell III ) and $\mathrm{III}_{\mathrm{II}}$ (cell III II), they were prepared from cell I and cell II, respectively. Cell I and cell II were soaked in $100 \%$ ethylenediamine for $24 \mathrm{~h}$ at ambient condition, washed with dried methanol and kept under vacuum.

The prepared cell $\mathrm{III}_{\mathrm{I}}$ and cell $\mathrm{III}_{\mathrm{II}}$ were further used for the preparation of celluloses $\mathrm{IV}_{\mathrm{I}}\left(\right.$ cell $\mathrm{IV}_{\mathrm{I}}$ ) and $\mathrm{IV}_{\mathrm{II}}$ (cell $\mathrm{IV}_{\mathrm{II}}$ ), by firstly soaking them in glycerol for $3 \mathrm{~d}$ at ambient condition. They were then heated in a reaction vessel at $260^{\circ} \mathrm{C} / 0.6 \mathrm{MPa}$ for $30 \mathrm{~min}$ and cooled down to ambient condition [34]. The product was, then, washed with water and acetone successively, and dried in vacuum. Basically, the converted celluloses consisted of

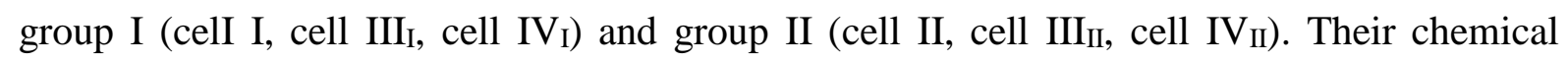
compositions were also analyzed and all these celluloses were found to contain similar monosaccharide components of about $99.9 \mathrm{wt} \%$ glucose and $0.1 \mathrm{wt} \%$ xylose [35].

To compare the decomposition products from the water-soluble (WS) portions on various types of crystalline celluloses by semi-flow HCW treatment, cellulose with similar 
$136 D P$ are necessary for their evaluation. Consequently, these celluloses were adjusted by trial 137 and error for their DPs by changing the treatment condition mentioned above for converting 138 cell I to various forms of celluloses.

140 The determination of $D P$ and crystallinity of the celluloses

141 The celluloses were dissolved in $0.5 \mathrm{M}$ cupriethylenediamine (Cuen) by viscometry as 142 per TAPPI method [36]. The DP of the celluloses was then calculated from the intrinsic 143 viscosity $[\eta]$ according to the equation $D P^{0.905}=0.75[\eta]$ [37]. For the crystallinity 144 determination, Gaussian functions were used to deconvulate the XRD patterns of various 145 crystalline celluloses [38]. These XRD patterns were recorded by X-ray diffractometer 146 Rigaku RINT 2200 [32].

Treatment of various crystalline cellulose samples by semi-flow HCW treatment

The prepared celluloses as starting materials were then treated individually in a semi-

150 flow HCW system. The conversion system and its operational procedures as explained elsewhere were adapted for this study [24-26]. Briefly, about $0.4 \mathrm{~g}$ of cellulose was treated individually within a $5 \mathrm{~mL}$ reaction vessel. The ambient distilled water from a water tank was flown through the reaction vessel by a pump in order to pressurize the system at $10 \mathrm{MPa}$ controlled by a back-pressure regulator. To raise the temperature, the preheating unit monitored by thermocouples was used to reach at the designated temperatures of 230,250 and $270^{\circ} \mathrm{C}$ for about 20 min under $10 \mathrm{MPa}$ and remain constant for additional $15 \mathrm{~min}$, totally $35 \mathrm{~min}$. In addition, another heating unit was installed at the reaction vessel to maintain the designated temperature in the reaction vessel, into which the HCW was passed through at the flow-rate of $10 \mathrm{~mL} / \mathrm{min}$. passing through the reaction vessel, the WS portions were cooled down immediately by the cooling system to terminate all reactions and collected every $5 \mathrm{~min}$. They were allowed to settle in ambient temperature and pressure for a minimum of $12 \mathrm{~h}$. Though no precipitation was observed after at least $12 \mathrm{~h}$, it was filtered by $0.45 \mu \mathrm{m}$ membrane prior to the subsequent analyses.

Analytical methods

The WS portions collected were analyzed and characterized by using high- 
170 chromatography (HPLC) and capillary electrophoresis (CE). The HPAEC system (Dionex 171 ICS-1000 system) equipped with the CarboPac PA-1 column (4 mm x $250 \mathrm{~mm}$ ) and electrochemical detector for pulsed amperometric detection was employed and operated at

$17335^{\circ} \mathrm{C}$ and flow-rate of $1.0 \mathrm{~mL} / \mathrm{min}$ under the helium atmosphere for monosaccharides and 174 cello-oligosaccharides in the WS portions. The mobile phase was a gradient-programmed mixture of deionized water, $0.2 \mathrm{M} \mathrm{NaOH}$ and $2.0 \mathrm{M} \mathrm{CH}_{3} \mathrm{COONa}$, as eluents. All eluents contained in 3 separate reservoirs were degassed by an aspirator and subsequently purged with helium to prevent the absorption of $\mathrm{CO}_{2}$.

The HPLC system (Shidmadzu, LC-10A) equipped with a Shodex Sugar KS801/Ultron PS-80P columns and refractive index/UV-Vis detector was applied. The eluent used was deionized water at a flow-rate of $1.0 \mathrm{~mL} / \mathrm{min}$ and oven temperature was set to be $80^{\circ} \mathrm{C}$ for the columns. The CE (Agilent; Germany) was used to assay the low molecular weight organic acids. A fused-silica capillary (Agilent; $75 \mu \mathrm{m}$ diameter, $104 \mathrm{~cm}$ total length, $95.5 \mathrm{~cm}$ effective length) was used at $15^{\circ} \mathrm{C}$.

Concentrations of the products in the WS portions were calculated based on the peak areas on chromatograms obtained from HPAEC, HPLC and CE. A set of standards with known concentrations, containing the compounds that were to be identified both quantitatively and qualitatively, was prepared and analyzed together with the samples by using the relevant analytical equipment as mentioned above [18, 24, 25].

\section{Results and Discussion}

To investigate the decomposition behaviors on various types of crystalline celluloses by semi-flow HCW treatment, the celluloses must have the same DPs as the starting materials. Thus, a direct comparison between the celluloses is feasible, as listed in Table 1. Treatments by semi-flow HCW were then carried out for these celluloses at temperatures of 230,250 and $270^{\circ} \mathrm{C}$ under $10 \mathrm{MPa}$ for $15 \min \left(230-270^{\circ} \mathrm{C} / 10 \mathrm{MPa} / 15 \mathrm{~min}\right)$.

Decomposition kinetics

The semi-flow HCW treatment decomposed various crystalline celluloses either partially or completely to the WS portions. The yield on WS portions from various crystalline celluloses as shown in Fig. 1, is a function of treatment temperatures. At constant treatment time, the yield on WS portions increased as the temperature increased. They were measurable even at lower temperature, $230^{\circ} \mathrm{C} / 10 \mathrm{MPa}$, with approximately $10-30 \mathrm{wt} \%$ and increased to more than $70 \mathrm{wt} \%$ at higher temperature, $270^{\circ} \mathrm{C} / 10 \mathrm{MPa}$. At $270^{\circ} \mathrm{C} / 10 \mathrm{MPa} / 15 \mathrm{~min}$, cell II 
204

205

206

207

208

209

210

211

212

213

214

215

216

217

218

219

220

221

222

223

224

225

226

227

228

229

230

231

232

233

234

235

236

was shown to be totally decomposed to WS portions as compared with other celluloses. The overall results from Fig.1 illustrated that higher yields were obtainable for group II celluloses than group I.

Figure 2 shows the Arrhenius plot of the present results according to the pseudo-firstorder reaction kinetics. The relationship between natural logarithms of reaction constants, $\ln k$, and $T^{-1}$ shows good linear fits with the results indicating that the decomposition follows the pseudo-first-order reaction kinetics. Every parameter used such as time, pressure and $D P$ on the celluloses were kept constant, satisfying the assumption that the Arrhenius-plot is temperature dependent. Though, the data points obtained in this study are only based on three different temperatures profile, the degree of decomposition could be determined reliably and the comparison of kinetics on various crystalline celluloses can be done directly.

The apparent activation energies, $E_{\mathrm{a}}$, for the celluloses can be calculated from Fig. 2. Activation energy of any reaction mainly explains its degree of temperature-sensitiveness; reactions with higher $E_{\mathrm{a}}$ are high in temperature-sensitiveness, while the reactions with lower $E_{\mathrm{a}}$ are low temperature-sensitive [39]. It can also be said that $E_{\mathrm{a}}$ is defined as the minimum energy required for decomposition to occur. The smaller $E_{\mathrm{a}}$ for decomposition of cellulose signifies the requirement of less energy for its decomposition and vice versa. In Fig.2, it was shown that different slopes obtained for each of the celluloses suggested different $E_{\mathrm{a}}$ for cellulose decomposition in the studied temperature range.

Table 2 shows the obtained $E_{\mathrm{a}}$ for all celluloses within the treatment temperatures. The $E_{\mathrm{a}}$ for group I and group II celluloses are, respectively, greater than $70 \mathrm{~kJ} / \mathrm{mol}$ and in between $50-60 \mathrm{~kJ} / \mathrm{mol}$. It is apparent that the celluloses in group I have higher $E_{\mathrm{a}}$ than those in group II, which implies an easier decomposition process for group II celluloses by semi-flow $\mathrm{HCW}$ treatment. However, due to the aforementioned limitations such as limited numbers of experiments carried out in a relatively narrow temperature range, the obtained $E_{\text {a }}$ must be judged critically. The acquired $E_{\mathrm{a}}$ was based on the best fit curves. As a result, a higher $E_{\mathrm{a}}$ was obtained for cell IV I as compared with cell I and cell IIII. Since comparison of $E_{\text {a }}$ was done between group I and group II, the above observation of group I having higher $E_{\mathrm{a}}$ than group II is valid.

These $E_{\mathrm{a}}$ are lower than previously reported, $164 \mathrm{~kJ} / \mathrm{mol}$ [7] and $145 \mathrm{~kJ} / \mathrm{mol}$ [40] without catalysts, whereas, $144 \mathrm{~kJ} / \mathrm{mol}$ and $100 \mathrm{~kJ} / \mathrm{mol}$ [41] in dilute sulfuric acid catalyst. The differences in $E_{\mathrm{a}}$ could be due to various definitions of decomposition processes and treatment conditions used. For instance, Sasaki et al. [40] studied just the kinetics of cellulose 
237

238

239

240

241

242

243

244

245

246

247

248

249

250

251

252

253

254

255

256

257

258

259

260

261

262

263

264

265

266

267

268

269

270

hydrolysis only at elevated temperatures (above $290^{\circ} \mathrm{C} / 25 \mathrm{MPa}$ ), whereby in this work the kinetics of various cellulose decomposition was measured at $230-270^{\circ} \mathrm{C} / 10 \mathrm{MPa}$.

Here, the observed decomposition of cellulose in subcritical water appears to be as good as that occurring in dilute sulphuric acid hydrolysis [41]. Cellulose firstly undergoes a rapid weight loss and followed by a slow hydrolysis step of the remaining cellulose. The high reactivity is associated with accessible amorphous regions in cellulose that are more vulnerable to chemical attacks than the crystalline regions [42]. The reaction temperature has influence on the solvent properties of water $[15,43]$. It has been suggested that the shift in solvent properties affects the kinetics of cellulose decomposition [44, 45]. However, in this present work, the constant $E_{\mathrm{a}}$ implies that the reaction mechanism of the hydrothermal decomposition is not distinctly affected. The lower $E_{\mathrm{a}}$ obtained indirectly showed that the decomposition of various celluloses in this system is a catalytic process, in agreement with the literature [41].

\section{Quantification of water-soluble (WS) portions}

Figure 3 shows the reaction scheme of cellulose I decomposition into hydrolyzed and degraded products as treated by semi-flow HCW treatment, adapted from [32]. In the present work, the WS portions for various crystalline celluloses obtained from each treatment were found to follow a similar decomposition pathway as in Fig. 3. It is important to know the decomposition pathway of cellulose as the degraded products inhibit the fermentation process for ethanol production [46].

Under the HCW conditions, the ionization constant of water increases with temperature and the amount of dissociation also increases, compared with normal temperature and pressure. The glucosidic linkages of cellulose are cleaved and cellulose starts to hydrolyze into cello-oligosaccharides, and subsequently, hydrolyzed to monosaccharide of glucose [20, 25, 47, 48]. Isomerization of glucose occurred producing fructose and mannose. These monosaccharides are unstable at high temperature and thus some parts of them are further converted into their degraded products such as furfural, 5-hydroxymethyl furfural (5HMF), levoglucosan through dehydration, and erythrose, glycolaldehyde, methylglyoxal through fragmentation [49]. Prolonged treatment, however, allows further degradation to take place, generating other products such as organic acids.

The resulted WS portion percentages based on the dried weight of cellulose samples clearly indicated that the celluloses have been converted to the hydrolyzed and degraded products. The hydrolyzed products are comprised of cello-oligosaccharides, glucose, fructose 
271

272

273

274

275

276

277

278

279

280

281

282

283

284

285

286

287

288

289

290

291

292

293

294

295

296

297

298

299

300

301

302

303

304

and mannose, whereas the degraded products consist of dehydrated and fragmented products, as well as organic acids. Their productions were recorded higher in hydrolyzed products as compared with degraded products, and more yields were obtained as treatment temperatures increased.

These WS portions were calculated similarly as in the previous studies [24, 25]. The cello-oligosaccharides were consisted of cellobiose, cellotriose, cellotetraose, cellopentaose, cellohexaose and other cello-oligosaccharides with the higher DP. The more existence of the cello-oligosaccharides with the higher $D P$ shows that the cellulose has more resistance against hydrolysis by semi-flow $\mathrm{HCW}$ treatment. In addition to cello-oligosaccharides and glucose, a smaller amount of fructose was also detected and only traces of mannose were identified.

A much lower yield of the WS portions obtained at $230^{\circ} \mathrm{C} / 10 \mathrm{MPa} / 15 \mathrm{~min}$ (data not shown) was due to the difficulty of the crystalline structures of celluloses to be hydrolyzed at such lower temperature [26]. The cello-oligosaccharides observed could be obtained from the paracrystalline cellulose. The observed fructose is not a sugar component in cotton linter, but it may be isomerized from glucose after hydrolysis from cellulose [50, 51].

To evaluate the decomposition behavior of various crystalline celluloses in details, the results from $270^{\circ} \mathrm{C} / 10 \mathrm{MPa} / 15 \mathrm{~min}$ would be more appropriate, as at this condition, crystalline cellulose is known to decompose [20, 25, 26]. Table 3 shows the comparison between hydrolyzed and degraded products for the two groups of cellulose samples at $270^{\circ} \mathrm{C} / 10 \mathrm{MPa} / 15 \mathrm{~min}$. It can be seen that for both group I and group II celluloses, more than $50 \mathrm{wt} \%$ of hydrolyzed products were obtained as compared with degraded products. It was reported that about 31.2, 28.1 and $20.5 \mathrm{wt} \%$ of hydrolyzed products obtained from the cellulose of Japanese cedar, Japanese beech and Nipa frond, respectively [52]. However, there were no results for $D P$ of the cellulose from this study that it can be compared with. The higher yield in WS portions observed in this present work could probably due to the shorter $D P$ celluloses used for the starting materials.

According to Fig. 3, the hydrolyzed products were produced at the early stage of cellulose decomposition pathway. This could signify that these celluloses have resistance against decomposition. The total hydrolyzed products for cell I and cell $\mathrm{III}_{\mathrm{I}}$ is similar but much lesser than cell IV I, whereas the highest hydrolyzed products obtained in group II is


more hydrolyzed products than those in group I. The observation is similar for the degraded products. 
Figures 4 and 5, respectively, illustrated how the hydrolyzed and degraded products

306

307

308

309

310

311

312

313

314

315

316

317

318

319

320

321

322

323

324

325

326

327

328

329

330

331

332

333

334

335

336

337

338 were obtained at every $5 \mathrm{~min}$ intervals at $270^{\circ} \mathrm{C} / 10 \mathrm{MPa} / 15 \mathrm{~min}$. In Fig. 4 , only the yields of cello-oligosaccharides, glucose and fructose were shown. These yields are comparable with the results in the literatures [20, 24-26]. Based on these results, the cellulose has been cleaved into cello-oligosaccharides at the early stage of the treatment time and the production of glucose and fructose was seen to occur simultaneously. Celluloses in both group I and group II have similar behaviors; however, more products were seen from group II celluloses. The cello-oligosaccharides and glucose were recovered from the treatment time of $35 \mathrm{~min}$. The crystalline structure of cellulose remained unchanged at temperatures around $230^{\circ} \mathrm{C}$ [53], thus, the WS portions emerged from the time-up (0-20 min treatment time) could be from paracrystalline cellulose, and the time-at (20-35 min treatment time) was from cellulose.

Generally, these monosaccharides are further degraded by dehydration or fragmentation process $[15,24,54,55]$. Figure 5 illustrated more dehydrated products were obtained than fragmented products and organic acids. During the treatments, it can be seen that the degraded products were generated at almost similar time as the hydrolyzed products (Fig.4). Moreover, the productions of dehydrated and fragmented products as well as organic acids were generated concurrently. Both group I and group II celluloses in Fig.5 have the same trends as in Fig. 4, i.e., more products resulted from group II celluloses. The generation of hydrolyzed products started to be noticeable from around 3 min (Fig. 4) and followed by degraded products (Fig. 5) about 10 min later. This sequence is parallel with that shown in Fig. 3 at which the hydrolyzed products were produced earlier in the decomposition pathway, and later on followed by the production of degraded products.

Figure 6 shows the yield in wt\% for the individual degraded products in the WS portions for both group I and group II celluloses as treated by semi-flow $\mathrm{HCW}$ at $270^{\circ} \mathrm{C} / 10 \mathrm{MPa} / 15 \mathrm{~min}$. The dehydrated products detected were consisted of furfural, 5HMF and levoglucosan, whereas fragmented products such as erythrose, glycolaldehyde and methylglyoxal. While for organic acids, acetic, formic, lactic and glycolic acids were identified. The furfural in Fig. 6 can not only be produced from pentose but also from hexose such as glucose. This means that the formation of furfural is possible without pentose via five-carbon ketoses pathway as proposed in the literature [56].

Glycolaldehyde and erythrose were formed via retro-aldol condensation in glycolaldehyde/erythrose pathway [44, 51], while methylglyoxal was produced via glyceraldehyde/dihdroxyacetone pathway in hexose fragmentation. Nevertheless, the production of methylglyoxal in this case was too minute that it was excluded from Fig.6. The 
339 production of furfural and 5HMF was significant as compared with other degraded products.

340 The organic acids produced are the results of further degradation of dehydrated and 341 fragmented products $[51,57]$. Lactic acid production was only a trace to be included in Fig. 6.

342 All the sequences of degradation reactions and productions are agreeable with Fig. 3.

343 Based on those results above, it can be seen that group II celluloses dominated both

344 the hydrolyzed and degraded products as compared with group I celluloses. The result on the

345 WS portions at $270^{\circ} \mathrm{C} / 10 \mathrm{MPa} / 15$ min revealed that the degree of difficulty for decomposition is greater for celluloses in group I than those in group II.

\section{Conclusion}

This study reveals the essential effects of various crystalline celluloses on their chemical decomposition and its kinetic behaviors as treated by semi-flow HCW. Both decomposition rate and $E_{\mathrm{a}}$ are helpful in defining the degree of difficulty for decomposition of various crystalline celluloses, however, the $E_{\mathrm{a}}$ obtained were merely based on empirical relationships of Arrhenius equation. Consequently, the direct method is more preferable than the latter. Nevertheless, this study showed the new kinetic data as there was no previous data on these specific reaction systems.

These treatments can be used as viable decomposition media for celluloses at which under the given treatment conditions, cellulose is more readily hydrolyzed with less degraded products. Group I celluloses (cell I, cell IIII, cell $\mathrm{IV}_{\mathrm{I}}$ ) have shown to have more resistance to

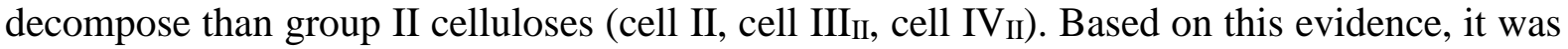
clear that the decomposition behaviors are due to the different crystalline forms of celluloses. Therefore, it is recommended to transform cellulose I to the other for a better hydrolysis reaction. These presented data are useful for understanding how various types of crystalline celluloses are chemically decomposed, providing useful insights to efficient utilization of lignocellulose for biofuels and biochemicals.

\section{Acknowledgement}

367 This work was supported by the Kyoto University Global GCOE program of 'Energy Science in the Age of Global Warming', to which authors are thankful. 


\section{References}

374 1. Bommarius AS, Katona A, Cheben SE, Patel AS, Ragauskas AJ, Knudson K, Pu Y (2008) Cellulase kinetics as a function of cellulose pretreatment. Metab Eng 10:370-381

376

377

378

379

380

381

382

383

384

385

386

387

388

389

390

391

392

393

394

395

396

397

398

399

400

401

402

403

404

2. O'Sullivan AC (1997) Cellulose: the structure slowly unravels. Cellulose 4:173-207

3. Klemm D, Heublein B, Fink HP, Bohn A (2005) Cellulose: fascinating biopolymer and sustainable raw material. Angew Chem Int Ed 44:3358-3393

4. Galbe M, Zacchi G (2002) A review of the production of ethanol from softwood. Appl Microbiol Biotechnol 59:618-628

5. Zugenmaier P (2008) Crystalline cellulose and cellulose derivatives: characterization and structures. Heidelberg, Germany, pp3-4

6. Mes-Hartree M, Dale BE, Craig WK (1988) Comparison of steam and ammonia pretreatment for enzymatic hydrolysis of cellulose. Appl Microbiol Biotechnol 29:462-468

7. Schacht C, Zetzl C, Brunner G (2008) From plant materials to ethanol by means of supercritical fluid technology. J Supercrit Fluids 46:299-321

8. Grous WR, Converse AO, Grethlein HE (1986) Effect of steam explosion pretreatment on pore size and enzymatic hydrolysis of poplar. Enzyme Microb Technol 8:274-280

9. Inoue H, Yano S, Endo T, Sasaki T, Sawayama S (2008) Combining hot-compressed water and ball milling pretreatments to improve the efficiency of the enzymatic hydrolysis of eucalyptus. Biotechnol Biofuels 1:1-9

10. Mosier N, Wyman C, Dale B, Elander R, Lee YY, Holtzapple M, Ladisch M (2005) Features of promising technologies for pretreatment of lignocellulosic biomass. Bioresour Technol 96:673-686

11. Camacho F, González-Tello P, Jurado E, Robles A (1996) Microcrystalline cellulose hydrolysis with concentrated sulphuric acid. J Chem Tech Biotechol 67:350-356

12. Karr WE, Holzapple MT (2000) Using lime pretreatment to facilitate the enzymatic hydrolysis of corn stover. Biomass Bioenergy 18:189-199

13. Targoński Z (1985) Alkali process for enhancing susceptibility of autohydrolysed beech sawdust to enzymatic hydrolysis. Enzyme Microb Technol 7:126-128

14. Saka S, Konishi R (2001) Chemical conversion of biomass resources to useful chemicals and fuels by supercritical water treatment. In: Bridgwater AV (ed) Progress in thermochemical biomass conversion. Blackwell, Oxford, pp1338-1348 
405

406

407

408

409

410

411

412

413

414

415

416

417

418

419

420

421

422

423

424

425

426

427

428

429

430

431

432

433

434

435

436

437

438

15. Kruse A, Dinjus E (2007) Hot-compressed water as reaction medium and reactant. Properties and synthesis reactions. J Supercrit Fluids 39:362-380

16. Bobleter O, Niesner R, Rohr M (1976) The hydrothermal degradation of cellulosic matter to sugars and their fermentative conversion to protein. J Appl Polym Sci 20:2083-2093

17. Bobleter O, Bonn G, Concin R (1983) Hydrothermalysis of biomass-production of raw material for alcohol fermentation and other motor fuels. Alternative En Sourc 3:323-332

18. Yu Y, Wu HW (2010) Understanding the primary liquid products of cellulose hydrolysis in hot-compressed water at various reaction temperatures. Energy Fuels 24:1963-1971

19. Hsu T-A (1996) Pretreatment of biomass. In: Wyman CE (ed) Handbook on bioethanol: production and utilization. Taylor and Francis, Bristol, pp179-195

20. Phaiboonsilpa N, Yamauchi K, Lu X, Saka S (2010) Chemical conversion of lignocellulosics as treated by two-step hot-compressed water. In Yao T (ed) Zero-Carbon Energy Kyoto 2009. Green Energy and Technology, Springer, Tokyo, pp166-170

21. Sasaki M, Kabyemela B, Malaluan R, Hirose S, Takeda N, Adschiri T, Arai K (1998) Cellulose hydrolysis in subcritical and supercritical water. J Supercrit Fluids 13:261-268

22. Saka S, Ueno T (1999) Chemical conversion of various celluloses to glucose and its derivatives in supercritical water. Cellulose 6:177-191

23. Kumar S, Gupta RB (2008) Hydrolysis of microcrystalline cellulose in subcritical and supercritical water in a continuous flow reactor. Ind Eng Chem Res 47:9321-9329

24. Lu X, Yamauchi K, Phaiboonsilpa N, Saka S (2009) Two-step hydrolysis of Japanese beech as treated by semi-flow hot-compressed water. J Wood Sci 55:367-375

25. Phaiboonsilpa N, Yamauchi K, Lu X, Saka S (2010) Two-step hydrolysis of Japanese cedar as treated by semi-flow hot-compressed water. J Wood Sci 56:331-338

26. Phaiboonsilpa N, Tamunaidu P, Saka S (2011) Two-step hydrolysis of nipa (Nypa fruticans) frond as treated by semi-flow hot-compressed water. Holzforschung 65:659-666

27. Adschiri T, Hirose S, Malaluan RM, Arai K (1993) Non-catalytic conversion of cellulose in supercritical and subcritical water. J Chem Eng Jpn 26:676-680

28. Ehara K, Saka S (2002) A comparative study on chemical conversion of cellulose between the batch-type and flow-type systems in supercritical water. Cellulose 9:301-311

29. Sakaki T, Shibata M, Sumi T, Yasuda S (2002) Saccharification of cellulose using a hotcompressed water-flow reactor. Ind Eng Chem Res 41:661-665 
30. Liu C, Wyman CE (2003) The effect of flow rate of compressed-hot water on xylan, lignin, and total mass removal from corn stover. Ind Eng Chem Res 42:5409-5416

31. Mok WS, Antal MJ Jr (1992) Uncatalyzed solvolysis of whole biomass hemicelluloses by hot-compressed liquid water. Ind Eng Chem Res 31:1157-1161

32. Abdullah R, Ueda K, Saka S (2013) Decomposition behaviors of various crystalline celluloses as treated by semi-flow hot-compressed water. Cellulose 20:2321-2333

33. Isogai A, Atalla RH (1998) Dissolution of cellulose in aqueous $\mathrm{NaOH}$ solutions. Cellulose 5:309-319

34. Isogai A, Usuda M, Kato T, Uryu T, Atalla RH (1989) Solid-state CP/MAS ${ }^{13}$ CNMR study of cellulose polymorphs. Macromolecules 22:3168-3172

35. TAPPI Standard Methods T222 om-88 1988

36. TAPPI Standard Methods T230 om-82 1982

37. Sihtola H, Kyrklund B, Laamanen L, Palenius I (1963) Comparison and conversion of viscosity and DP-values determined by different methods. Paperi ja Puu 45:225-232

38. Park S, Baker JO, Himmel ME, Parilla PA, Johnson DK (2010) Cellulose crystallinity index: measurement techniques and their impact on interpreting cellulase performance. Biotechnol Biofuels 3:1-10

39. Xin J, Imahara H, Saka S (2009) Kinetics on the oxidation of biodiesel stabilized with antioxidant. Fuel 88:282-286

40. Sasaki M, Adschiri T, Arai K (2004) Kinetics of cellulose conversion at $25 \mathrm{MPa}$ in suband supercritical water. J Amer Inst Chem Engrs, 50:192-202

41. Mok WSL, Antal MJ, Varhegyi G (1992) Productive and parasitic pathways in dilute acid-catalyzed hydrolysis of cellulose. Ind Eng Chem Res. 31:94-100

42. Sasaki M, Fang Z, Fukushima Y, Adschiri T, Arai K (2000) Dissolution and hydrolysis of cellulose in subcritical and supercritical water. Ind Eng Chem Res 39:2883-2890

43. Marshall WL, Franck EU (1981) Ion product of water substance, 0-1000 ${ }^{\circ}$, 1-10000 bars new international formulation and its background. J Phys Chem Ref Data $10: 295-304$

44. Sasaki M, Furukawa M, Minami M, Adschiri T, Arai K (2002) Kinetics and mechanism of cellobiose hydrolysis and retro-aldol condensation in subcritical and supercritical water. Ind Eng Chem Res 41:6642-6649

45. Deguchi S, Tsujii K, Horikoshi K (2008) Crystalline-to-amorphous transformation of cellulose in hot and compressed water and its implications for hydrothermal conversion. Green Chem 10:191-196 
473

474

475

476

477

478

479

480

481

482

483

484

485

486

487

488

489

490

491

492

493

494

495

496

497

498

499

500

501

502

503

504

505

46. Palmqvist E, Hahn-Hägerdal B (2000) Fermentation of lignocellulosic hydrolysates. II: Inhibitors and mechanisms of inhibition. Biores Technol 74:25-33

47. Antal MJ, Mok WSL (1990) Four-carbon model compounds for the reactions of sugars in water at high temperature. Carbohydr Res 199:111-115

48. Kruse A, Gawlik A (2003) Biomass conversion in water at $330-410^{\circ} \mathrm{C}$ and $30-50 \mathrm{MPa}$. Identification of key compounds for indicating different chemical reaction pathways. Ind Eng Chem Res 42:267-279

49. Antal Jr MJ, Mok WSL (1990) Mechanism of formation of 5-(hydroxymethyl)-2furaldehyde from D-fructose and sucrose. Carbohydr Res 199:91-110

50. Srokol Z, Bouche AG, Estrik AV, Strik RCJ, Maschmeyer T, Peters JA (2004) Hydrothermal upgrading of biomass to fuel; studies on some monosaccharide model compounds. Carbohydr Res 339:1717-1726

51. Kabyemela BM, Adschiri T, Malaluan RM, Arai K (1999) Glucose and fructose decomposition in subcritical and supercritical water: detailed reaction pathway, mechanisms and kinetics. Ind Eng Chem Res 8:2888-2895

52. Phaiboonsilpa N, Saka S (2012) Hydrolysis behaviors of lignocellulosics as treated by two-step semi-flow hot-compressed water. Proceedings of the 10th International Symposium on Supercritical Fluids (ISSF 2012), May 13-16, 2012, San Fransisco, California, USA: http://issf2012.com/handouts/documents/144_004.pdf Accessed 10 April 2014

53. Phaiboonsilpa N, Lu X, Yamauchi K, Saka S (2009) Chemical conversion of lignocellulosics as treated by two-step semi-flow hot-compressed water. In: Proceedings of the World Renewable Energy Congress 2009 - Asia, May 19-21, 2009, Bangkok, Thailand, pp 235-240

54. Kumar S, Gupta R, Lee YY, Gupta RB (2010) Cellulose pretreatment in subcritical water: Effect of temperature on molecular structure and enzymatic reactivity. Bioresour Technol 101:1337-1347

55. Xiao LP, Sun ZJ, Shi ZJ, Xu F, Sun RC (2011) Impact of hot-compressed water pretreatment on the structural changes of woody biomass for bioethanol production. BioResource 6:1576-1598

56. Kallury RKMR, Ambidge C, Tidwell TT, Boocock DGB, Anglevor FA, Steward DJ (1986) Rapid hydrothermolysis of cellulose and related carbohydrate. Carbohydr Res 158:253-261 
506 57. Yoshida K, Kusaki J, Ehara K, Saka S (2005) Characterization of low molecular weight

507 organic acids from beech wood treated in supercritical water. Appl Biochem Biotechnol

508 121-124:795-806

509

510

511

512

513

514

515

516

517

518

519

520

521

522

523

524

525

526

527

528

529

530

531

532

533

534

535

536

537

538

539 


\section{$540 \quad$ List of figure captions}

541

542 Fig. 1 The yield on WS portions from various types of crystalline celluloses as treated at 543 different temperatures under $10 \mathrm{MPa}$ for $15 \mathrm{~min}\left(230-270^{\circ} \mathrm{C} / 10 \mathrm{MPa} / 15 \mathrm{~min}\right)$ by semi-flow $544 \mathrm{HCW}$

546 Fig. 2 The Arrhenius plot for various crystalline celluloses using pseudo-first order reaction 547 kinetics as treated by semi-flow $\mathrm{HCW}$ at $230-270^{\circ} \mathrm{C} / 10 \mathrm{MPa} / 15 \mathrm{~min}$

549 Fig. 3 Decomposition pathway of crystalline cellulose I as treated by semi-flow HCW

551 Fig. 4 The hydrolyzed products of cello-oligosaccharides, glucose and fructose in the WS

552 portions from various types of crystalline celluloses as treated by semi-flow $\mathrm{HCW}$ at $553270^{\circ} \mathrm{C} / 10 \mathrm{MPa} / 15 \mathrm{~min}$. Top figure corresponds to treatment temperature (open squares)

555 Fig. 5 The degraded products of dehydrated, fragmented and organic acids products in the

556 WS portions from various types of crystalline celluloses as treated by semi-flow HCW at $557270^{\circ} \mathrm{C} / 10 \mathrm{MPa} / 15 \mathrm{~min}$. Top figure corresponds to treatment temperature (open squares)

559 Fig. 6 The degraded products in WS portions from various types of crystalline celluloses as 560 treated by semi-flow $\mathrm{HCW}$ at $270^{\circ} \mathrm{C} / 10 \mathrm{MPa} / 15 \mathrm{~min}$ 


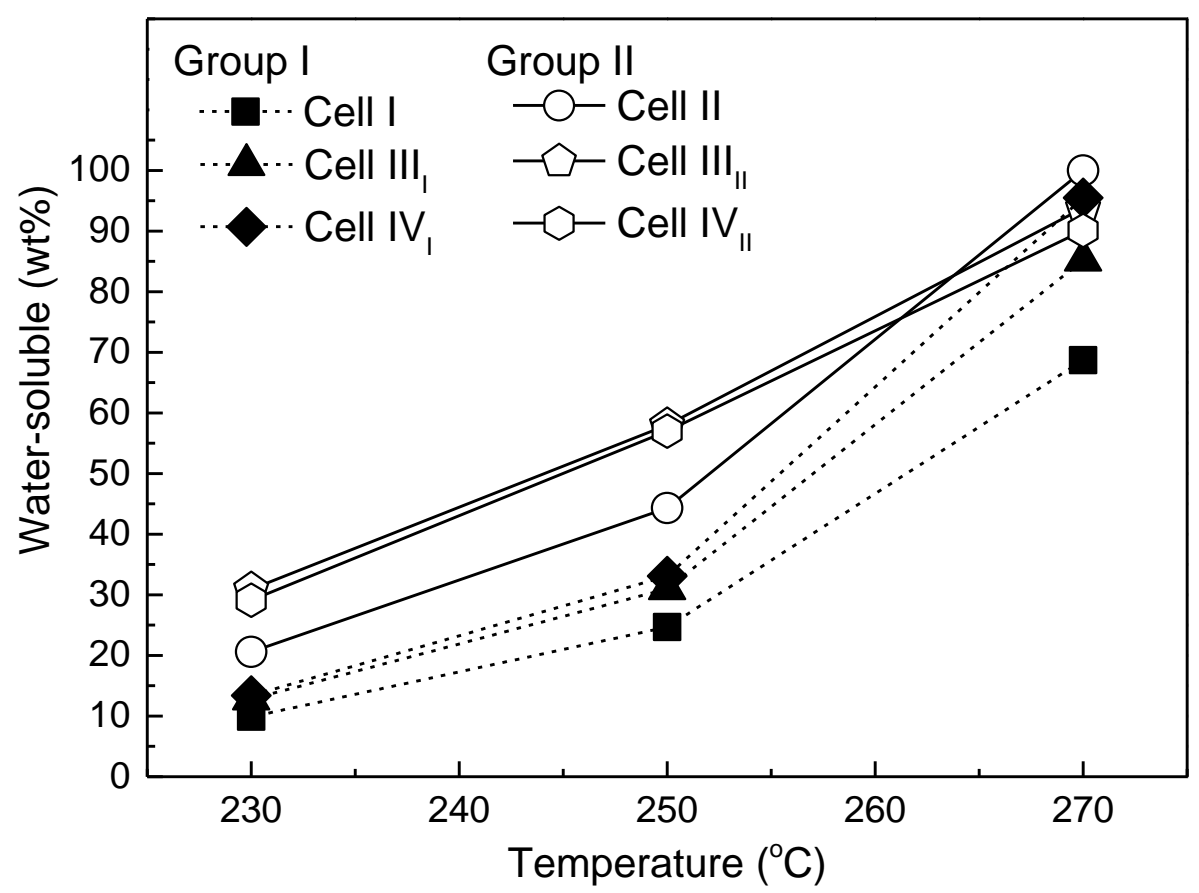

Fig. 1 The yield on WS portions from various types of crystalline celluloses as treated at different temperatures under $10 \mathrm{MPa}$ for $15 \mathrm{~min}\left(230-270^{\circ} \mathrm{C} / 10 \mathrm{MPa} / 15 \mathrm{~min}\right)$ by semi-flow $\mathrm{HCW}$ 


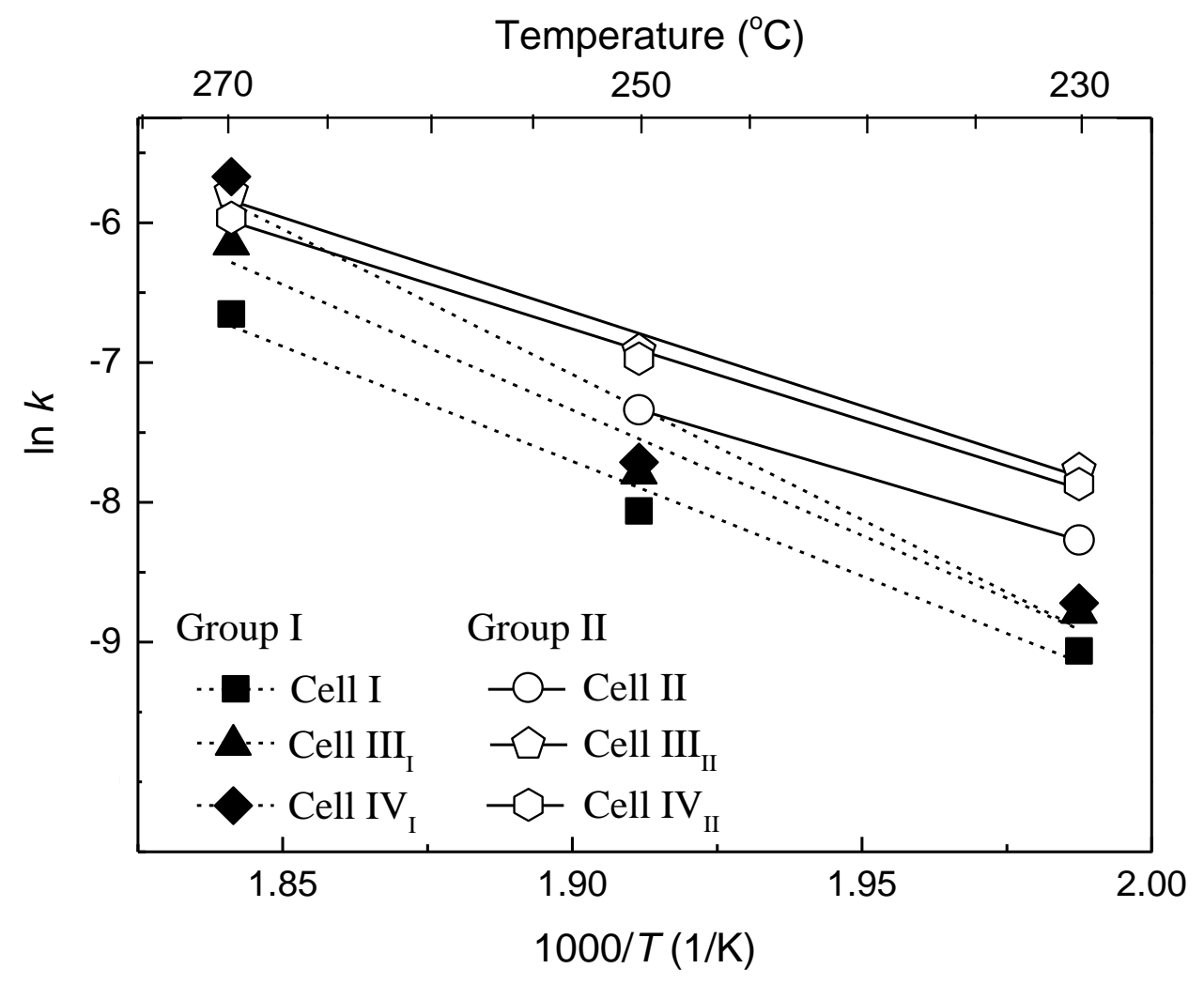

Fig. 2 The Arrhenius plot for various crystalline celluloses using pseudo-first order reaction kinetics as treated by semi-flow $\mathrm{HCW}$ at $230-270^{\circ} \mathrm{C} / 10 \mathrm{MPa} / 15 \mathrm{~min}$ 


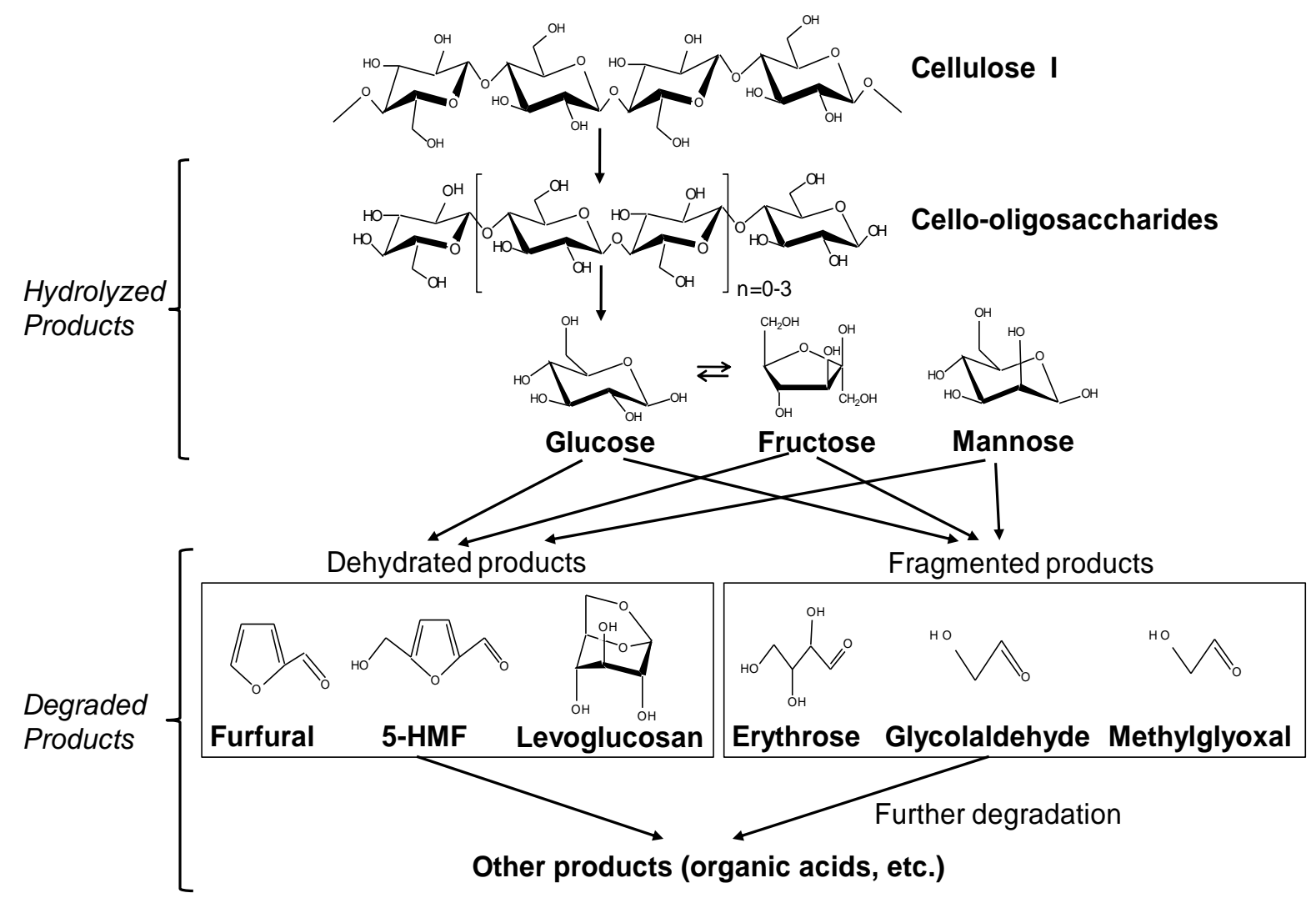

Fig. 3 Decomposition pathway of crystalline cellulose I as treated by semi-flow HCW 


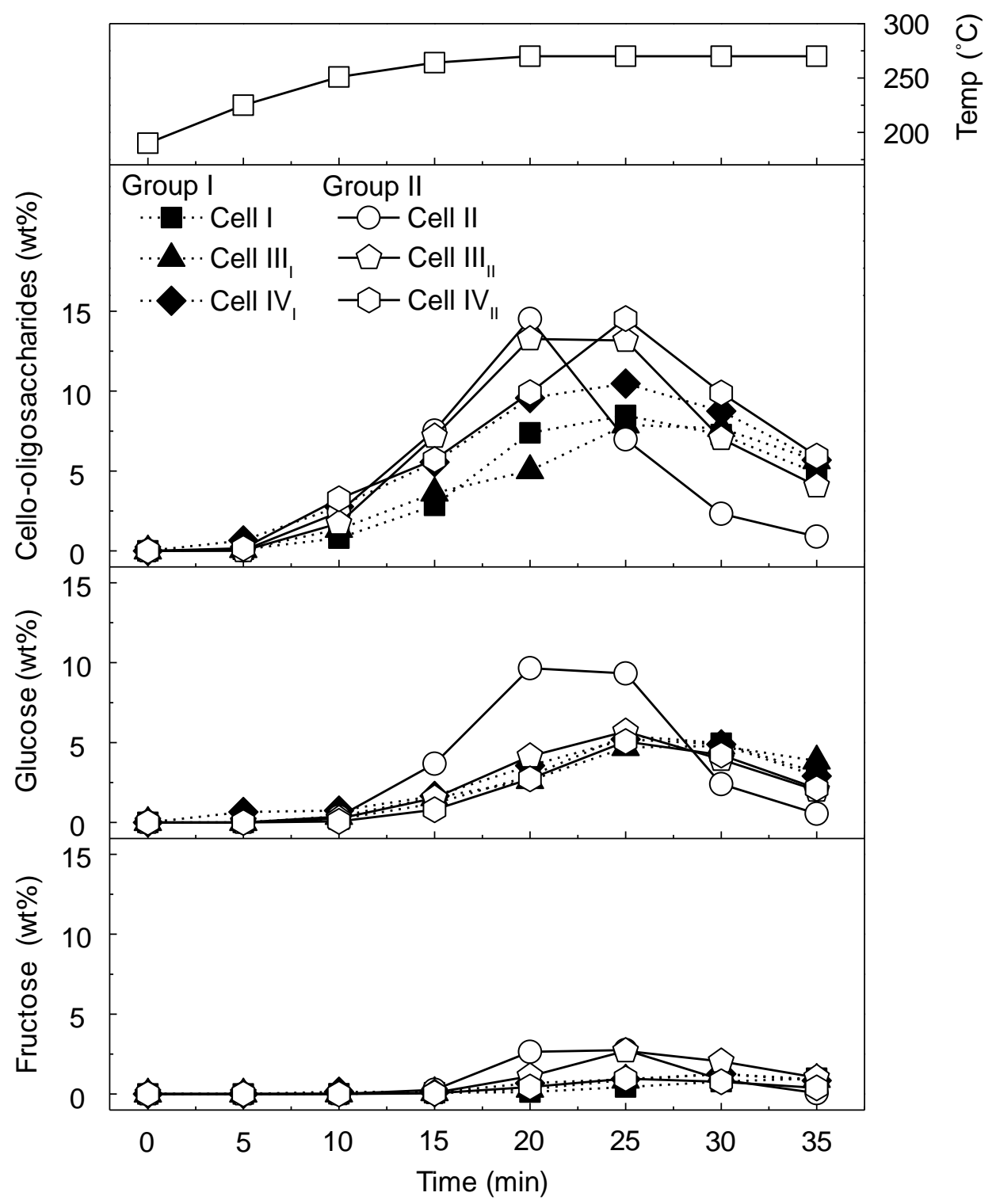

Fig. 4 The hydrolyzed products of cello-oligosaccharides, glucose and fructose in the WS portions from various types of crystalline celluloses as treated by semi-flow HCW at $270^{\circ} \mathrm{C} / 10 \mathrm{MPa} / 15 \mathrm{~min}$. Top figure corresponds to treatment temperature (open squares) 


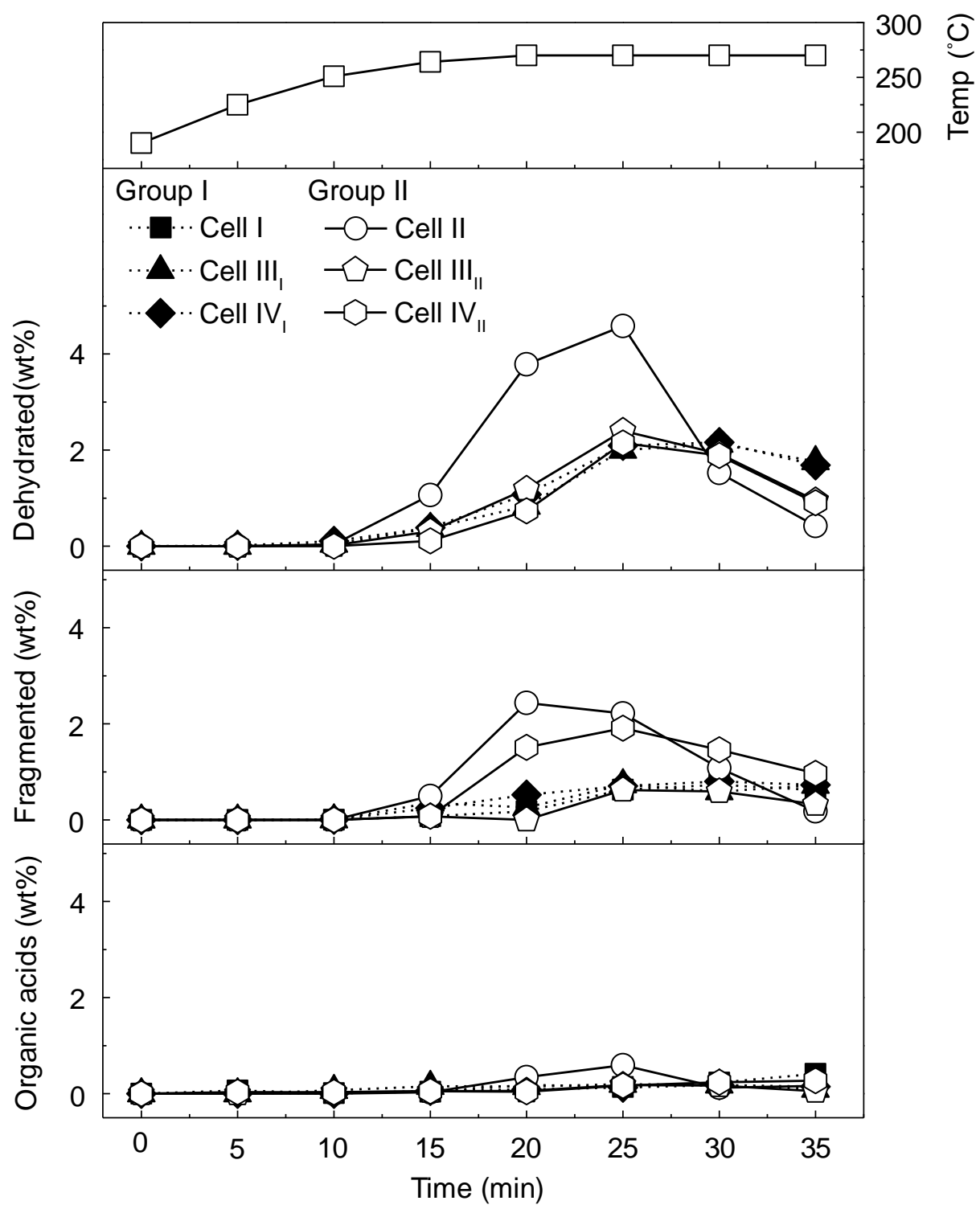

Fig. 5 The degraded products of dehydrated, fragmented and organic acids products in the WS portions from various types of crystalline celluloses as treated by semi-flow HCW at $270^{\circ} \mathrm{C} / 10 \mathrm{MPa} / 15 \mathrm{~min}$. Top figure corresponds to treatment temperature (open squares) 


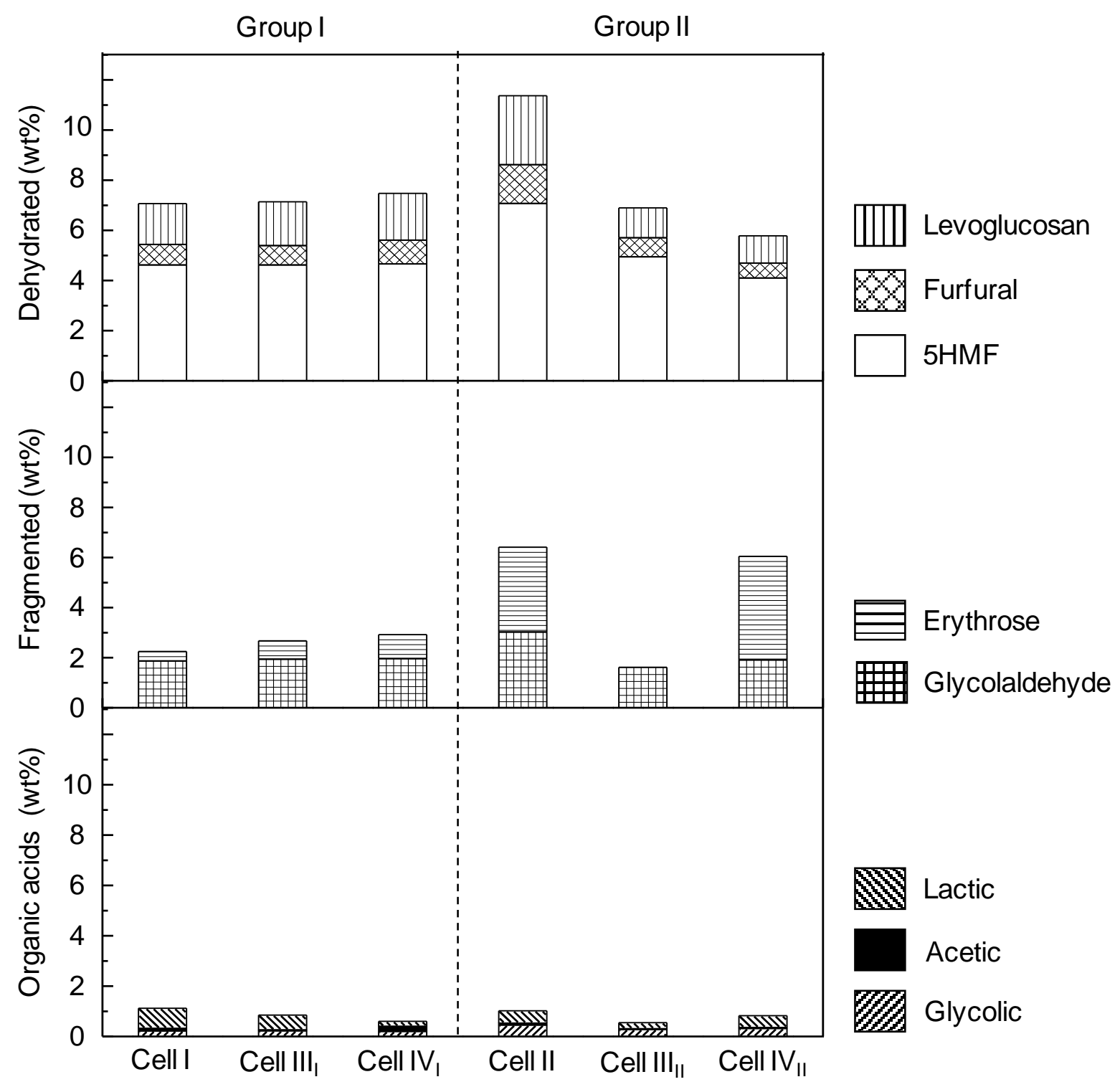

Fig. 6 The degraded products in WS portions from various types of crystalline celluloses as treated by semi-flow $\mathrm{HCW}$ at $270^{\circ} \mathrm{C} / 10 \mathrm{MPa} / 15 \mathrm{~min}$ 
Table 1 The crystallnity and $D P$ for various types of crystalline celluloses prepared in this study

\begin{tabular}{clcl}
\hline & Cellulose & Crystallinity (\%) & $D P$ \\
\hline \multirow{3}{*}{ Group I } & Cell I & 92 & 176 \\
& Cell III & 86 & 164 \\
& Cell IV $_{\text {I }}$ & 90 & 167 \\
\hline \multirow{3}{*}{ Group II } & Cell II & 85 & 173 \\
& Cell III & 87 & 176 \\
& Cell IV $_{\text {II }}$ & 85 & 164 \\
\hline
\end{tabular}


Table 2 The apparent activation energies of various types of crystalline celluloses as treated by semi-flow $\mathrm{HCW}$ at $230-270^{\circ} \mathrm{C} / 10 \mathrm{MPa} / 15 \mathrm{~min}$

\begin{tabular}{clc}
\hline & Cellulose & Activation energy, $E_{\mathrm{a}}(\mathrm{kJ} / \mathrm{mol})$ \\
\hline \multirow{3}{*}{ Group I } & Cell I & 71.4 \\
& Cell III & 78.0 \\
& Cell IV & 90.2 \\
\hline \multirow{3}{*}{ Group II } & Cell II & 53.3 \\
& Cell III & 59.0 \\
& Cell IV $_{\text {II }}$ & 56.6 \\
\hline
\end{tabular}


Table 3 The total hydrolyzed and degraded products of WS portions from various types of crystalline celluloses as treated by semi-flow $\mathrm{HCW}$ at $270^{\circ} \mathrm{C} / 10 \mathrm{MPa} / 15 \mathrm{~min}$

\begin{tabular}{llcc}
\hline & Cellulose & Hydrolyzed product $(\mathrm{wt} \%)$ & Degraded product $(\mathrm{wt} \%)$ \\
\hline \multirow{3}{*}{ Group I } & Cell I & 52.0 & 10.5 \\
& Cell III & 52.7 & 10.6 \\
& Cell IV & 67.0 & 11.1 \\
\hline \multirow{3}{*}{ Group II } & Cell II & 67.3 & 18.8 \\
& Cell III & 71.0 & 8.9 \\
& Cell IV $_{\text {II }}$ & 67.0 & 12.6 \\
\hline
\end{tabular}

